\title{
National language within Language Ecology Framework: A Threat to Vernacular Languages?
}

\author{
${ }^{*}$ Faizatul Husna \\ ${ }^{1}$ Department of Sociology, Faculty of Social and Political Science, University of Teuku \\ Umar, Meulaboh 23615, Indonesia; \\ email: faizatulhusna88@gmail.com
}

\begin{abstract}
Abstrak
Pemilihan bahasa Indonesia sebagai bahasa nasional, dimulai puluhan tahun silam sejak bangsa Indonesia berjuang meraih kemerdekaan terhadap Belanda. Puncaknya, Sumpah Pemuda pada tanggal 28 Oktober 1928 memberikan 'status' yang lebih tinggi kapada bahasa Indonesia diantara bahasa daerah lain. Oleh sebab itu, status bahasa Indonesia sebagai bahasa nasional harus mempertimbangkan eksistensi bahasa-bahasa lokal dalam lingkup ekologi bahasa, untuk menjamin keberlangsungan bahasa lokal di masa yang akan datang. Penelitian dokumenter ini bertujuan untuk menyibak proses sejarah perencanaan bahasa (language planning) dan perkembangan bahasa Indonesia era paska kolonial, dimana bahasa Indonesia terpilih untuk menyatukan ratusan bahasa daerah lain. Penelitian ini didasarkan atas laporan media terkemuka di Indonesia (The Jakarta Post, Nova, Republika dan Kompas) dan artikel yang berkaitan dengan isu pergeseran, pemertahanan dan ancaman bahasa daerah serta langkah-langkah yang diambil untuk melindungi bahasa daerah yang minoritas
\end{abstract}

Kata kunci: bahasa daerah, status, pergeseran dan pemertahanan, ekologi bahasa.

\section{INTRODUCTION}

Indonesia, a multiethnic nation located in South-East Asia, is the home for more than 1700 islands and 746 indigenous languages which spoken by hundreds of ethnic groups (Widodo and Fardhani, 2013). Historically, Indonesian language (formerly Malay) was chosen among three languages namely Malay, Javanese (local language) and Dutch (colonial language) immediately after Indonesia gained independence from Dutch colonization (Paauw, 2009). In fact, no more than 5\% of the population in the archipelago spoke Malay at Independence Day. Therefore, presumably, the establishment of Indonesian language was listed as one success story of language policy all over the world (Lauder, 2008; Paauw, 2009).

Both of the terms, language planning and language policy, have been used to explain a deliberate consideration, usually by the Government, in choosing an official 
language for a country. Generally, there are two types of language planning which drawn by Heinz Kloss (1967) in (Meshtrie, et. al, 2009); corpus planning has come to be used to refer to the internal structure of language, and status planning which refers all efforts made to change the use and function of a language in certain society, thus a language might acquire new status in a nation.

First of all, this documentary research aims to reveal the historical process of language planning and development in Indonesia on the post-colonial era, for which Indonesian language was elected to unify hundreds of local languages across the vast archipelago. Then it will also analyse the status and power of Indonesian language as national lingua franca (NLF) to the existence of indigenous languages in Indonesia as well as to investigate the factors lay behind the shift and maintenance in the number of local language use as indicated from news reports of some salient newspapers in Indonesia. Last, but not least, this study set out to present some possible solutions offered from the news reports to perpetuate the existence of those minority languages.

\section{LITERATURE REVIEW}

\subsection{Early Language policy and planning (LPP) in Indonesia}

Before starting to discuss language policy and planning practice in Indonesia, I will briefly introduce both planning and policy terms through the sociolinguistic perspective. To begin with, language planning and policy (henceforth LPP) was first introduced in 1950s by Einar Haugen, an American linguist, who examined a new standard language in Norway (Mesthrie, et.al, 2009). Language planning is defined as an action taken by stakeholders or elites at national level to authoritatively intervene the structure and function of a language. Whereas, language policy refers to a set of guidelines composed to the language planning (Tollefson, 2008; Ferguson, 2006).

In his earlier work, Fishman (1979) divides the language planning into two broad categories namely corpus planning and status planning. Mesthrie, et al (2009) define corpus planning as the forms of language planning which are concerned with the internal structure of a language, whereas status planning refers to an endeavour made to shift a position of language vis a vis other languages in political and sociocultural context. Fishman (1979) illustrates the relationship between corpus planning and status planning as two inseparably linked aspects in the following quote:

[Status] planning without concomitant corpus planning runs into a blind alley. Conversely, corpus planning without status planning is linguistic game, a technical exercise without social consequence (p.12) 
From the above idea, it can be inferred that when status planning might be defined as deliberate action to change the function and status of a language for a particular reason and purpose i.e. local language turns into official language, then corpus planning may explain how forms in that language are functioned when it serves as an official language, as such in educational or social context. Therefore, corpus planning may be success if it successfully applied in status planning of a language. Liddicoat and Baldauf (2008) further add language planning also embrace, 'language-in-education (or acquisition) planning (about learning), and (most recently) prestige planning (about image)'.

In Indonesia, the choice of national language has arisen some previous decades ago as Indonesia was seeking independence from Dutch colonialization (Paauw, 2009). Apparently, at that time, there were three languages spoken by indigenous Indonesian in the archipelago: Malay (a historic lingua franca for the archipelago), Javanese (the main indigenous language in Java) and Dutch (language used in the colonial period). Paauw (2009) and Sneddon (2003) further narrate that Malay language gradually became an important language since Malay homeland is located in trade route, reinforced its status as a prominent language for the trade affair and at the same time served as a lingua franca of the archipelago. Thereupon, when Indonesia was trying to achieve independence from Dutch, Indonesia's official language was possibly elected from one of those three superior languages which emerged in the archipelago at that moment. Ferguson (2006) explains that the transformation of Malay into an official language from language planning perspective has marked an important process in the development of a new national identity and nation-building.

In this case, Malay language is considered as the most suitable language to opt not only because this particular language has served as lingua franca for a long periods of time, but also it has been regarded as the easiest language to acquire in comparison with other languages with the more complex grammar (Paauw, 2009). Thereupon, even though Javanese as a prominent native language was spoken by the vast majority of Indonesia's population, yet the spread of the language was only concentrated in Java region and, admittedly, rather difficult to learn for non-native Javanese, makes it hardly possible to be selected. Similarly, Dutch language failed to opt due to its use was only limited to specific group of people such as local nobility and elites. Finally, a decision was made by Indonesia's leaders from 1926 to 1928 to officially acknowledge the status of Malay language as national language of Indonesia; on the latter year a new name, Indonesian or Bahasa Indonesia, was announced and reinforced by the oath as the replacement of Malay name, aimed to build a cultural entity of a new nation. The oath was taking place on 28 October 1928 by the representative of young people from the salient archipelago across Indonesia in the well-known The Youth Pledge Day (Sumpah Pemuda). Below is the excerpt of the pledge: 
"kami putra dan putri Indonesia menjunjung tinggi Bahasa persatuan, Bahasa Indonesia"

We, the sons and daughters of Indonesia, vow to uphold the nation's language of unity, Indonesian

The vow immediately gave Indonesian not only a new status and higher prestige as National Language or National Lingua Franca (NLF), but also generated a historical success story of language planning in Indonesia. However, the strory has not ended yet. After some periods after the pledge, in 1942 Japanese occupied the archipelago and forced to embed the Japanese language in Indonesia; anyhow, the influence of Indonesian language is even more stronger as the language has been widely used in educational level and in mass media.

It should be noted, however, that it is not only the status of language which marks the successful implementation of a language, however, the acceptance of language itself into society has also been regarded as an important key to the language planning success. Haugen (1966) in Meshtrie, et al (2009) mentions this kind of acceptance as the 'acceptability criterion' which indicates that the language planning which proposed by national-level stakeholders is recognized by the targeted society. As for Indonesia's case, Paauw (2009) mentions some reasons lay behind the recognition of national language, such as the function of language as national lingua franca in the archipelago, and as representative of cultural identity of a new developing nation.

\subsection{Vernacular Languages in Ecology: Shift, Maintenance and Death}

From the elaboration of early language policy and planning in Indonesia, it can be understood that for some considerations a language may gain a higher status and power vis-a-vis other languages. Paauw (2009) has outlined that the chosen of the formerly Malay language might eliminate conflicts among ethnic in Indonesia and at the same time aims to unify Indonesian people under the Indonesia's motto of Bhineka Tunggal Ika or Unity in Diversity. However, despite Indonesian as the statutory national language are now officially used in educational and formal institutions, in fact, most of terrain languages are still spoken in daily life for some purposes. For indigenous people, their native language is more than a vehicle to communicate. Apart from that, language might be considered as a gift of the cultural heritage that they guard until they are ready to pass it on to their next generation. Then when it changes or loss, their identity will be obsolescent. This beautiful reflection has been beautifully portrayed in McCarty, Romero and Zepeda (2006) in language loss and revitalization issues. 
However, questions might arise on whether this superordinate language at a certain degree may diminish the use and the users of minority languages in Indonesia. On the one hand, Arka (2013) argues that the pressure of dominant languages in Indonesia towards the less minority ones may lead to endangerment, a term which is firstly coined by Cameron (1995) to describe any kinds of threats which affect the indigenous language in the linguistic border. On the other hand, Nababan (1991) reveals that indigeneous languages in Indonesia, are able to maintain until now in spite of the rapid spread of national language because the language itself have obtained special position and value in the middle of society long before independence day.

Put it all together, the terms such as language maintenance, shift and death are categorized into subfield of sociolinguistics within the scope of language contact. To gain a better understanding of how language endangerment issues particularly to minority languages which occurred throughout the world, some articles have been previously published in Duchene and Heller (2007), i.e Pujolar, Jaffe and Crowley in studying Catalan, Corsican and Gaelic or Boudreau and Dubois, in examining the particular issues of language endangerment and preservation of indigeneous languages with the attachment of social and cultural issues might be useful. In addition, Meshtrie, et al (2009) describes language maintenance as the vitality of a language to survive in the presence of other languages. Meanwhile, language shift can be explained as the replacement of particular language use in communication as the influence of more powerful language. It may be concluded that language shift could happen because of a language is less powerful over the other languages, thus the more powerful language will shift the minority one which has previously existed. The last term, language death is described as a condition when the language is scarcely spoken due to lack of users or the speakers of that language in certain community are the last generation in the world.

This particular relationship between the minority languages vis-a-vis homogeneous language, will be best illustrated under the language ecology framework. Creese and Martin (2003) explain the language ecology as, “...the relationship of languages to each other and to the society in which these languages exist. This includes the geographical, socio-economic and cultural conditions in which the speakers of given language exist, as well as the wider linguistic environment." (p.1). It can be inferred that languages, speakers and environment that sustain or influence the existence of local languages are inextricably linked to each other. This ecology system also tells us how particular languages are able to evolve in particular situation and environment, while others are marginalized as the result of the influence or pressure of prominent language. However, it is important to note that term 'minority' is not always necessarily used as the size representation when compared to the majority one, but it may also refer to the symbol of lesser power, rights and priviledges (Tollefson, 1991). When this language-ecology paradigm comes into multilingual language policy and practice, we will gain an understanding of how 
languages are then threatened to extinction. As Honberger (2003) insists that some languages can be threatened if there is lack support from the language environment itself. Therefore, the process of language planning and policy of languages are suggested to be fully aware of the natural cycle of language ecology.

\section{METHODOLOGY}

In this study, documentary research method as proposed by Scott (1990) is applied in order to analyze the relevant information which appears in documents and contemporary literature. In this light, documents are described as 'accounts, returns, statutes, and proclamations' which generated from daily people practice. Meanwhile contemporary literature is categorized as a residual term for all other written sources such as newspaper. For Scott (2009), both categories can be regarded as documents and are available through the research library or the internet.

This study will be drawn based on media reports from some salient newspapers in Indonesia (i.e The Jakarta Post, Nova, Republika and Kompas) and articles relevant to the issue of local language shift, maintenance, and endangerment as well as the steps taken to protecting local minority language. Also, what Pujolar (2007) mentioned as 'participant constellation' as to refer the participants involved in the activity such as the speaker, audiences, etc and their position to the issues will also be examined. It is also important to note that in analyzing the text, as Cohen (1999, p.81) inserts, we need to be careful of 'the semiotics of text production, how meaning is made in text, how readers take meaning from text, the status of authorial intention versus the reader's interpretation and the role of the community of discourse in the reception of text.

\section{DISCUSSION}

\section{The Influence of National Language to Minority Languages}

According to the National Education Ministry from the data published by UNESCO, Atlas of the World's Language in Danger of Disappearing, more than 154 local languages in Indonesia require attention as the number of diminishing languages are likely to increase from year to year; 139 of them are threatened with extinction, while 15 languages are completely extinct. Most cases happened are reported in the eastern part of Indonesia with some reasons behind its reduction. In presenting the status of some terrain languages in order to measure the how far the languages are developing or diminishing, I use the Expanded Fishman's GIDS scale (Lewis and Simons 2010). Starting with Indonesian as national language, indubitable the language marked as safe at level 1 since the language is actively used in education, work and media on nationwide scale. The dominant status of the language is also supported by the 
Community: Volume 4, Nomor 1, April 2018

ISSN: 2477-5746

language standardization from the apparatus of nation-state and the acceptance of targeted community.

Assessing Endangerment: Expanding Fishman's GIDS,

\begin{tabular}{|c|c|c|c|}
\hline \multicolumn{4}{|c|}{ Expanded Graded Intergenerational Disruption Scale (adapted from Fishman 1991)* } \\
\hline LEVEL & LABEL & DESCRIPTION & UNESCO \\
\hline 0 & International & $\begin{array}{l}\text { The language is used internationally for a broad range } \\
\text { of functions. }\end{array}$ & Safe \\
\hline 1 & National & $\begin{array}{l}\text { The language is used in education, work, mass media, } \\
\text { government at the nationwide level. }\end{array}$ & Safe \\
\hline 2 & Regional & $\begin{array}{l}\text { The language is used for local and regional mass } \\
\text { media and governmental services. }\end{array}$ & Safe \\
\hline 3 & Trade & $\begin{array}{l}\text { The language is used for local and regional work by } \\
\text { both insiders and outsiders. }\end{array}$ & Safe \\
\hline 4 & Educational & $\begin{array}{l}\text { Literacy in the language is being transmitted through } \\
\text { a system of public education. }\end{array}$ & Safe \\
\hline 5 & Written & $\begin{array}{l}\text { The language is used orally by all generations and is } \\
\text { effectively used in written form in parts of the } \\
\text { community. }\end{array}$ & Safe \\
\hline $6 a$ & Vigorous & $\begin{array}{l}\text { The language is used orally by all generations and is } \\
\text { being learned by children as their first language. }\end{array}$ & Safe \\
\hline $6 b$ & Threatened & $\begin{array}{l}\text { The language is used orally by all generations but } \\
\text { only some of the child-bearing generation are } \\
\text { transmitting it to their children. }\end{array}$ & Vulnerable \\
\hline 7 & Shifting & $\begin{array}{l}\text { The child-bearing generation knows the language } \\
\text { well enough to use it among themselves but none are } \\
\text { transmitting it to their children }\end{array}$ & $\begin{array}{c}\text { Definitely } \\
\text { Endangered }\end{array}$ \\
\hline $8 \mathrm{a}$ & Moribund & $\begin{array}{l}\text { The only remaining active speakers of the language } \\
\text { are members of the grandparent generation. }\end{array}$ & $\begin{array}{c}\text { Severely } \\
\text { Endangered }\end{array}$ \\
\hline $8 b$ & $\begin{array}{l}\text { Nearly } \\
\text { Extinct }\end{array}$ & $\begin{array}{l}\text { The only remaining speakers of the language are } \\
\text { members of the grandparent generation or older who } \\
\text { have little opportunity to use the language. }\end{array}$ & $\begin{array}{l}\text { Critically } \\
\text { Endangered }\end{array}$ \\
\hline 9 & Dormant & $\begin{array}{l}\text { The language serves as a reminder of heritage identity } \\
\text { for an ethnic community. No one has more than } \\
\text { symbolic proficiency. }\end{array}$ & Extinct \\
\hline 10 & Extinct & $\begin{array}{l}\text { No one retains a sense of ethnic identity associated } \\
\text { with the language, even for symbolic purposes. }\end{array}$ & Extinct \\
\hline
\end{tabular}

Table 1. EGIDS from SIL 
Then, other minority languages in Indonesia are vary in function and position based on EGIDS scales. Apparently, based on the data presented in Ethnologue, there is no local language in Indonesia which functions as a Regional language (at level 2). Javanese, as the largest local language, without acquiring official status occupies level 4 as the Education language as this language gained more powerful status over other minority languages in Indonesia and might still be used for educational purpose, thus this local language is predicted to maintain for quite longer time in the future. Some indigenous languages may be classified at the specific level based on the number of speakers and the power they possess. However, as it is also indicated from the table, that the indigenous languages is reduced significantly in the number of its use and users. As for example two indigenous languages in central Flores namely Rongga, (Arka, 2005) and Tomini-Tolitoli in Sulawesi (Himmelmann, 2010) have been reported as unusual diminish by the oppression of more dominant languages and being under pressure of Indonesian.

Nevertheless, from the reliable Ethnologue database, Rongga language with more than 4000 speakers is classified at level 6a or vigorous as it still being spoken and learnt as children's first language. Meanwhile in some parts of Indonesia TominiTolitoli with total 25.000 language speakers are labelled shifting with national language, thus put it down to a level 7 . This condition somewhat justifies the conclusion made by Tollefson (1991) that talking about minority language is not merely about the size or number of speakers, but it also concerned with power of that language possess to be able to maintain and evolve in ecology system. Or it is somewhat related to what Coulmas (2013) argues about the adherence of the local people themselves to use the language.

To provide another sample of language endangered, an article from Republika (2015) reveals that Oirata language in Maluku province is severely endangered to level 8 a (moribund) because only grandparents in a family speak the language while they will always code-switch to other dominant language when communicate with their descendants. Indeed, the endorsing of Indonesian language as national language more or less has change parents perspective toward the implementation of language education to their children. Some researchers i.e. Grimes (2002) and Widodo and Fardhani (2013) expose that most parents nowadays urge their children to speak Indonesian to improve socio-economic status in the future. As it is plausible to say that nowadays certain language has become an absolute prerequisite to achieve a higher degree of education, which in turn, will help the students to get a good job and a higher salary in the future, leads more and more parents to send their children to the schools that promote national language even international language.

On the contrary, Felicia Nuradi Utorodewo (2014), director of the Southeast Asian Ministers of Education Organization's Regional Center for Quality Improvement of Teachers and Educational Personnel, argues that the using of first language or mother tongue in learning will gradually develop their cognitive skill in learning, as 
the lesson will be more comprehensible in their mother tongue. Thus she suggests that school where children learning must support the application of local language in the classroom before they are ready to get introduced to other languages. This notion at the same time is also trying to encourage the use of local language in the formal institution in order to preserve it from marginalization.

Another report from Nova (2015), a well-known family tabloid in Indonesia, which recently made a polling on the International Mother Tongue day which falls every 21 February each year, showing that the majority of mothers in Indonesia are still passing on the local language to their children at home. However several mothers who opt not to teach their children the language mostly because they have moved far away from the community who speak the language and they also rarely take their children coming back to the hometown due to the lack of money (Kompas, 2015). Therefore, shifting to national language might be the best choice for them. Another issue related to language shift from terrain language to dominant language is social prestige and status. Sugiharto (2007) in The Jakarta Post states that some people assume that using national language in communication will heighten their social status and prestige. On the contrary, people who communicate with the using of local language when interacting with other people who usually communicate in national language, tend to be excluded from that communication relationship.

To sum up, it might be true that the domination of national language to some extent will influence the existence of indigenous languages in a language ecology system. Some reasons to the critical endanger local language arise from news and articles are a) competition with more dominant language, b) socio-economic, status and privilege c) languages are only transmitted trans generationally within a family, c) local languages are only spoken by old generation d)limited support from institution such as school.

\section{Proposed solution to protecting local languages}

There should be no further questions addressed now about the status of Indonesian as a national language since it is the realization of all people dream in the nation. Likewise, it is also an undeniable fact that the use of national language is almost always adjoined with local language, as most people will communicate in both languages alternately. On the surface, this situation is perhaps viewed as a harmony in diversity. However, some others may still anticipate the problems that might potentially appear in relevance to this dominant-minority relationship, included the threat to minority language. Sugiharto (2013) argues that the threat of local language extinction may happen due to the lack implementation of the minority language policy. Within the sheer absence of this policy, protection of minority languages in the midst of competition cannot be guaranteed. Aware of this condition, the protection of local languages viability has been actually composed in the enactment of autonomy laws, 
UU 221999 on Local Autonomy and The 1945 Constitution of the Republic of Indonesia, state that the authority of the local languages is entrusted to local governments. This law also implicitly underpin the language promotion through education and ensure every language has the same right.To support implementation process, we also need to understand the concept of Linguistic Human Rights or LHRs in which the aim is to promote language equality and justice so that the speakers of language are gaining right to learn his/ her mother tongue and having education through it (Phillipson, Rannut, and Skutnabb-Kangas, 1994).

Therefore, on any condition, the presence of hundreds of local languages should indeed enrich cultural heritage in a nation instead of becoming a multilingual problem. Likewise, if the homogeneity language concept is strongly promoted, particularly in educational setting, it will generate a greater pressure to the indigenous language, which in turn, may contribute to the language stagnancy. Hence, according to Lauder (2005) by creating a policy, under the protection of law, to promote a harmonious relationship between national language and local language will eventually help reducing the number of critical local languages

Lauder (2012), a prominent Indonesian linguist, also elaborates that position of a language in Indonesia could be even more in danger due to the unavailability of the writing systems or vocabulary to practice by the communities since communication is mostly conducted orally. Therefore, he believes that constructing an official writing system or help creating a dictionary will be helpful to maintain the presence minority language. It is important to bear in mind that preserving language is a long term process with the continuous endeavour. Thus, it would be beneficial if the government together with stakeholders pays more attention to this issue and realizing the proposed program along with financial support toward the program.

\section{CONCLUSION}

It is true that language extinction within the ecology system is a natural process and is sometimes beyond our control, moreover in a multi-ethnic nation type as in Indonesia (Lauder, 2008). However, there is still some efforts and strategies that can be done to prevent it by identifying the key factors lay behind the extinction. Recent evident have shown that the indigenous language is reduced in the number of its users. As Coulmas (2013) has elaborated, there are two factors which determine the viability of language: micro-social arena which is started form family setting and determine the language transmission; and macro-social which refer to 'territory'. Yes, the extent of government involvement as the above top-down macro perspective, will not be successful if there is not supported by micro-level categories such as from family setting. This, eventually, will ensure the languages can grow healthily in language ecosystem with the support of its environment, policy makers and societies. 


\section{REFERENCES}

Arka, I. W. (2005, July). Spatial expressions in Balinese and Rongga. In Congress of the Indonesian Linguistics Society, Padang, Indonesia (pp. 18-21).

Arka, I. W. (2013). Language management and minority language maintenance in (eastern) Indonesia: strategic issues. Retrieved from http://scholarspace.manoa.hawaii.edu/bitstream/handle/10125/4568/Arka.pdf?sequ $\underline{\text { ence }=5}$

Bahasa daerah semakin punah [Local language under threat of extinction]. (2014, March 5). Republika. Retrieved from http://www.republika.co.id/berita/koran/news-update/14/03/04/n1wzn0-bahasadaerah-semakin-punah

Bahasa daerah terancam. [Local languages are threatened].(2015, March 26).Kompas. Retrieved from http:// print.kompas.com/baca/2015/03/26/Bahasa-DaerahTerancam

Coulmas, F. (2013). Sociolinguistics: The study of speakers' choices. Cambridge University Press.

Creese, A., \& Martin, P. (2003). Multilingual classroom ecologies: Inter-relationships, interactions and ideologies. International Journal of Bilingual Education and Bilingualism, 6(3-4), 161-167.

Duchêne, A,. \& Heller, M. (Eds.). (2007). Discourses of endangerment: Ideology and interest in the defence of languages. Bloomsbury Publishing.

Lauder, A. (2008). The status and function of English in Indonesia: a review of key factors. Makara, Sosial Humaniora, 12(1), 9-20.

Lewis, M. P., \& Simons, G. F. (2010). Assessing endangerment: expanding Fishman's GIDS. Revue roumaine de linguistique, 2, 103-119.

Liddicoat, A., \& Baldauf, R. B. (Eds.). (2008). Language planning and policy: Language planning in local contexts. Multilingual Matters.

McCarty, T. L., Romero, M. E., \& Zepeda, O. (2006). Reclaiming the gift: Indigenous youth counter-narratives on Native language loss and revitalization. The American Indian Quarterly, 30(1), 28-48. 
64

Community: Volume 4, Nomor 1, April 2018

ISSN: 2477-5746

Mesthrie, et.al. (2009). Introducing sociolinguistics. Edinburgh University Press.

Paauw, S. (2009). One land, one nation, one language: An analysis of Indonesia's national language policy. University of Rochester Working Papersin the Language Sciences, vol5, 1, 2-16.

Phillipson, R., Skutnabb-Kangas, T., \& Rannut, M. (1994). Linguistic human rights. Mouton, Berlin.

Pupils learn best in local languages, say. (2014, September 26). Retrieved from http://www.thejakartapost.com/news/2014/09/26/pupils-learn-best-locallanguages-say.html

Scott, J. (2014). A matter of record: Documentary sources in social research. John Wiley \& Sons.

Sugiharto, S. (2013). Indigenous language policy as a national cultural strategy. The Jakarta Post. Retrieved from

http://www.thejakartapost.com/news/2013/10/28/indigenous-language-policy-anational-cultural-strategy.html\#sthash.T7pwnbVq.dpuf

Sugiharto, S (2007) Indigenous languages in danger of disappearing. The Jakarta Post. Retrieved from http://www.thejakartapost.com/news/2007/10/27/indigenouslanguages-danger-disappearing.html-0

Sugiyono. (n.d) Pelindungan Bahasa Daerah dalam Kerangka Kebijakan Nasional Kebahasaan [Local language protection within the national language policy framework]. Retrieved from http:// blog.apastyle.org/apastyle/2010/11/how-to-cite-something-you-foundon-a-website-in-apa-style.html

SURVEI NOVA: Mayoritas Ibu di Indonesia Sudah Mengajarkan "Bahasa Ibu" pada Anak [NOVA SURVEY: Most Indonesian moms have started to teach "mother tongue" to their children]. (2015, February 28). NOVA. Retrieved from http://www.tabloidnova.com/Nova/Keluarga/Anak/SURVEI-NOVA-MayoritasIbu-di-Indonesia-Sudah-Mengajarkan-Bahasa-Ibu-pada-Anak-2/

Widodo, H. P., \& Fardhani, A. E. (2013). The language rights of indigenous languages: An approach to maintaining Indonesia's linguistic and cultural diversity. New York: Nova Science Publishers, Inc. 